\title{
为基础研究的繁荣发展作出新贡献
}

白春礼

\section{Make new contributions to thriving basic research}

\section{Chunli Bai}

doi: 10.1360/TB-2020-1184

基础研究是科学之本、技术之源, 是科技进步的 先导, 是自主创新的源泉. 习近平总书记在 2020 年 9 月 11 日召开的科学家座谈会上深刻指出, 我国面 临的很多“卡脖子”技术问题, 根子是基础理论研究 跟不上, 源头和底层的东西没有搞清楚. 只有持之 以恒加强基础研究, 不断强基固本, 才能为科技创 新提供源源不竭的动力. 向科学技术广度和深度进 军, 必须持之以恒加强基础研究. 习近平总书记的 重要论述为“十四五”时期以及更长时期我国基础研 究的繁荣发展和原始创新能力的全面提升指明了前 进方向、提供了根本遵循.

党的十八大以来, 在以习近平同志为核心的党

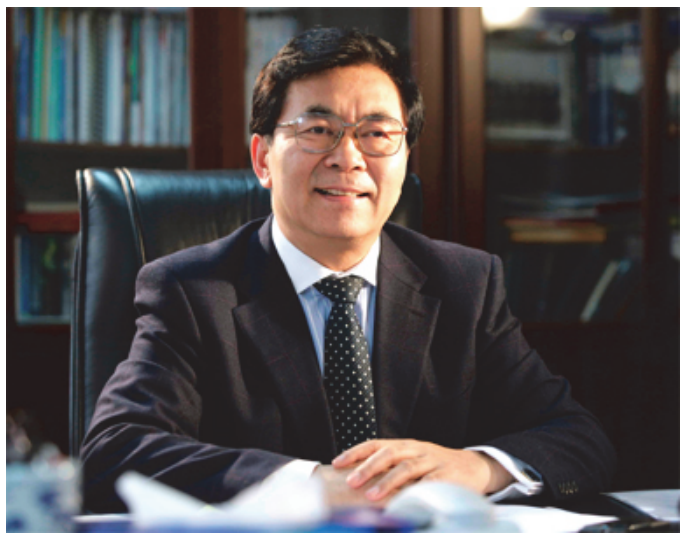

白春礼

中国科学院院长、党组书记 中国科学院学部主席团执行主席 陈嘉庚科学奖基金会理事长 中央坚强领导下，通过全社会共同努力，我国科技事业取得历史性成就、发生历史性变革. 重大原创成果竞相涌现, 一些前沿领域开始进入并跑、领跑阶段. 化学、材料、物理等学科 整体水平进入国际先进行列, 在量子信息、铁基超导、中微子、千细胞、脑科学等世界科学 前沿领域取得系列重大原创成果, 国际科技论文数量和高被引论文数量均位居世界第 2 位, 为人类科技发展作出了重要贡献. 总体来看, 我国基础研究的整体实力显著增强，已进入从 量的积累迈向质的飞跃、从点的突破迈向系统能力提升的关键阶段.

在总结成绩的同时我们也要清醒地认识到, 我国的基础研究和原始创新能力与世界先 进水平相比还有不小差距. 一是规律级、体系级、学科级的重大原创成果还比较少, 不少研 究仍然处于跟踪模仿和补充重复阶段. 二是能够改变领域国际格局、引领学科发展方向的大 师级人物和战略科学家还比较稀缺, 青年拔尖人才的成长还不能完全适应基础研究加快发 展的需要. 三是有利于科研人员专心致研的学术环境、社会环境还有待完善, 一些体制机制 障碍制约了创新活力的充分释放. 四是基础研究的投入强度还需要进一步加大，投入渠道 
还需要进一步拓展.

当今世界正经历百年末有之大变局，国内外环境正在发生深刻复杂变化。我国科技创新 既面临赶超跨越的难得历史机遇, 也面临差距拉大的严峻挑战, 唯有勇立世界科技创新潮 头, 提升国家科技整体实力和发展潜力, 特别是加快提升基础研究和原始创新能力, 才能赢 得发展主动权. 要按照习近平总书记在科学家座谈会上的重要讲话要求, 认真做好前瞻谋 划和重点领域布局, 同步抓好奇心驱动的探索性研究和重大科技问题带动的应用型基础研 究; 要加大基础研究投入，在增加财政投入的同时鼓励引导企业、金融机构、社会资金多渠 道投入，扩大资金来源，形成持续稳定投入机制; 要创造有利于基础研究的良好科研生态, 建立健全科学评价体系、激励机制, 鼓励广大科研人员解放思想、大胆创新, 让科学家潜心 搞研究; 要尊重人才成长规律和科研活动自身规律, 培养造就一批具有国际水平的战略科 技人才、科技领军人才、创新团队, 逐步形成开放有序、动态流动、充满活力的人才制度. 通 过多措并举加快实现我国基础研究能力和水平质的跃升, 为建设世界科技强国提供有力支 撑, 为推动人类文明进步作出更多中国贡献.

陈嘉庚科学奖基金会是以我国著名爱国侨领陈嘉庚先生名字命名的基金会, 旨在弘扬 陈嘉庚先生爱国兴学、无私奉献的精神, 激励做出重要原创性科学技术成果的优秀科学家, 以促进我国科学技术事业的发展. 自 2003 年设立以来, 陈嘉庚科学奖和陈嘉庚青年科学奖 始终秉持鼓励原始创新、鼓励基础研究的理念, 先后奖励了 35 项原创成果和 26 位杰出青年 科学家, 为推动我国基础研究的发展做出了重要贡献. 陈嘉庚科学奖与陈嘉庚青年科学奖 也以科学的评选标准、规范的运行机制以及客观公正的评选结果赢得了社会各界、特别是 科技界的赞誉, 成为我国含金量高、公信力强、影响力大的重要科技奖项之一, 不仅鼓舞了 广大科技工作者努力攀登科技高峰, 而且在全社会弘扬了科学精神和科学风尚.

近期, 经过严格评审, 2020 年度陈嘉庚科学奖和青年科学奖顺利产生, “实验发现五夸克 态”等 5 个项目获得陈嘉庚科学奖, 关启安等 6 人获得陈嘉庚青年科学奖. 获奖项目都是我 国基础原创领域的最新重要进展, 代表了我国基础研究的实力和潜力. 《科学通报》出版 2020 年度陈嘉庚科学奖专辑, 对于宣传推介获奖项目和科学家, 提升奖项的影响力具有重 要作用.

建设创新型国家和世界科技强国是党和国家赋予新时代科技工作者的历史使命. 陈嘉 庚科学奖基金会将与全国科技界一道，深入贯彻落实习近平新时代中国特色社会主义思想， 以弘扬勇于探索、求真务实的科学精神为已任, 努力营造良好的学术生态, 促使科技人员的 创新智慧竞相迸发、原创成果大量涌现, 为我国基础研究的繁荣和科技事业的发展作出更大 贡献. 